\title{
Microbial profile of street food from different locations at Tumkur, India
}

\author{
Sudeep Kumar $\mathbf{M}^{1}$, Krishnamurthy Veena ${ }^{2}$, E R Nagaraj ${ }^{3}$ \\ ${ }^{1}$ Dr. Sudeep Kumar M, Associate Professor, ${ }^{2}$ Dr. Veena Krishnamurthy, Associate Professor, ${ }^{3}$ Dr. E.R Nagaraj, \\ Professor; all authors are attached with Department of Microbiology, Sri Siddhartha Medical College, Tumkur, B.H. \\ Road, Agalkote, Tumkur, Karnataka, India.
}

Address for Correspondence: Dr. Veena Krishnamurthy, Email: veena_kumara@rediffmail.com

\begin{abstract}
Introduction: The street food provided in ready -to-eat form are prepared and sold by vendors and hawkers in the street and other public places are a major source of foodborne diseases. Aim: The present study was undertaken to detect the causative agents in street foods and to determine their antibiotic susceptibility pattern. Settings and Design: Crosssectional study. Materials and Methods: Food samples and Ice-creams collected from street vendors, fast food joints were homoginized, serially diluted up to $10^{-5}$ and $1 \mathrm{ml}$ was seeded on to Blood agar, MacConkey agar and other bacteriological media. Results: Eighty Percentages of samples had pathogens. Salads were highly contaminated in 19 food outlets, followed by cut fruits, fast food -1(pani-puri, bhel-puri, masala puri), fast food-2 (noodles, fried rice, lemon rice). The antibiotic sensitivity pattern revealed Staphylococcus aureus (27.08\%) were resistant to ampicillin gentamicin $(23.95 \%)$, ciprofloxacin $(18.75 \%)$. Escherichia coli were resistant to ampicillin, ciporofloxacin. Salmonella sps isolated were resistant to ampicilin, gentamicin $(20.88 \%)$, ciprofloxacin, amikacin and co-trimoxazole (13.54\%). The resistance exhibited by Shigella sps were only $(2.08 \%)$. Vibrio sps showed resistance to ampicillin, gentamicin, ciprofloxacin, amikacin and co-trimoxazole Discussion: Salads had the highest number of pathogens (19.79\%) followed by cut fruits, fast food-1 and 2. Staphylococcus aureus (7.26\%), E.coli and Salmonella sps (5.20\%) respectively were isolated. High counts of Staphylococcus aureus could be due to poor personal hygiene of the food handlers and lack of heat processing steps during preparation. Conclusion: Education of the public and eating establishments is crucial to the control of food borne illness.
\end{abstract}

Key words: Food handlers, Carriers, Street foods, Vendors

\section{Introduction}

Food, microorganisms and humans have had a long and interesting association that developed long before recorded history. Microorganisms are associated in various ways with all the food we eat. Food can serve as ideal culture medium for the growth of microorganisms which can cause decomposition, spoilage and also serve as a vehicle for transmission of food borne illness. Food borne infection involves the ingestion of the pathogen, followed by growth and multiplication in the host including tissue invasion and /or the release of toxins [1]. Food borne illness is a major universal health problem in developing countries due to difficulties in safe guarding food from cross-contamination. Low

Manuscript received: $18^{\text {th }}$ March 2017

Reviewed: $26^{\text {th }}$ March 2017

Author Corrected: $4^{\text {th }}$ April 2017

Accepted for Publication: $11^{\text {th }}$ April 2017 income countries face the highest burden of diarrhoeal and other food borne disease associated with consumption of contaminated food. Transmission of enteropathogenic bacteria occur through faecal contamination of food, water, nails, fingers indicating the significance of faeco-oral route of transmission $[2,3]$.

The street food industry which provides street food in ready -to-eat form are prepared and sold by vendors and hawkers in street and other public places including schools, markets, parks etc are a major source of foodborne diseases. A street food vender is defined as a person who offers food for sale to public without permanent built up structure but a temporary static or mobile stall [4]. 
Street vended food provides a source of inexpensive, convenient and nutritious food for urban and rural population in developing countries [5].

Microbial contamination of ready-to-eat foods sold by street vendors and hawkers has become a major health problem as street vendors are ill informed of good hygiene practices, causes of diarrhoeal disease and risk of contamination. The hygiene aspects of vending operations are a major source of concern like stands are often crude structures, running water, washing facilities, are inadequately available. Washing of hands, utensils and dishes often is done in buckets or bowls.

Unorganised waste disposal and improper disinfection attracts insects and rodents around. Lastly food is not well protected from flies and refrigeration is not available $[6,7]$.

Vendors can be carriers of pathogens like E.coli, Salmonella sps, Shigella sps, Campylobacter and Staphylococcus aureus who can eventually transfer these food-borne hazards to consumers [8].

Tumkur is a district head quarters with a population of 5 lakhs in about $600 \mathrm{sq} \mathrm{km}$ geographical area. Availability of street food for consumption is not uncommon in major parts of Tumkur. There were quite a few outbreaks of food borne infections in the past but no recorded information is available with either public or private health care agencies. In view of all these aspects mentioned above, the present study was undertaken with an aim to detect the causative agents from food samples obtained from street-vendors and fast-food joints, determine the antibiotic susceptibility pattern and assess the status of food borne infections in Tumkur.

\section{Materials and Methods}

Study Setting: street vendors and fast-food out-lets in Tumkur town

Study Duration: 6 month period (July to Dec 2015)

Study Design: a cross- sectional study

Sampling Method: all street vendors and fast- food out-lets were included

Exclusion Criteria: establishments with permanent building were excluded from the study

Variables: all types of food items and juices available from each vendor.
Statistical methods: descriptive statistics, rates and proportions are used to describe the no. of food items showing organisms and also different types of organisms

Sources of Food: The following were considered as major samples for detection of causative agents of foodborne infections, salads, ice-cream, milk products, cut fruits, fast food-1 (pani-puri, bhel-puri, masala puri), fast food -2 (noodles, fried rice, lemon rice).

\section{Collection of Samples:}

Food Samples: Food samples and Ice-creams were collected at random from 20 different street food vendors and fast food joints in suitable sterile containers or sterile grease proof paper $[9,10]$.

\section{Processing of Samples}

Food samples: $10 \mathrm{~g}$ of each food sample was homoginized with mortar and pestle or blender, the resultant homogenate were aseptically added to $9 \mathrm{ml}$ sterile normal saline and serially diluted up to $10^{-5}$.

Using the spread plate technique $1 \mathrm{ml}$ of the dilution was seeded on the following differential and selective media Mac Conkey agar, Salmonella and Shigella agar and Blood agar [9].

Ice cream was melted before examination and diluted with ringer solution and processed as other foods [9].

\section{Isolation of causative agents:}

The samples were streaked on Mac Conkey agar, Salmonella and Shigella agar and Blood agar.

The causative agents were identified by standard colony morphology, microscopic findings, biochemical tests and agglutination with specific antisera for Salmonella, Shigella and Vibrio sps. Kirby Bauer disc diffusion method of antibiotic sensitivity was done as per Clinical and Laboratory Standards Institute (CLSI) guidelines using a wide panel of antibiotics.

Ampicillin $(10 \mu \mathrm{g})$, gentamicin $(10 \mu \mathrm{g})$, ciprofloxacin $(5 \mu \mathrm{g})$, amikacin $(30 \mu \mathrm{g})$, co-trimoxazole $(25 \mu \mathrm{g})$, cefotaxime $(30 \mu \mathrm{g})$, ceftazidime $(30 \mu \mathrm{g})$, ceftazidime clavulanic acid $(20 / 10 \mu \mathrm{g})$, amoxycllin/clavulanic acid

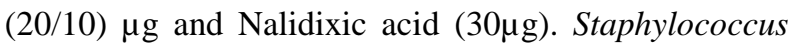
aureus ATCC 25923 and Escherichia coli ATCC 25922 were used as controls in the study [11]. 


\section{Research Article}

Cefoxitin disk diffusion tests were performed for all Staphylococcus aureus. isolates as recommended by the (CLSI) (2015).

A suspension of each isolate was made so that the turbidity was equal to a 0.5 McFarland standard and then plated onto Mueller-Hinton agar.
A $30 \mu \mathrm{g}$ cefoxitin disc (Oxoid) was applied to each plate. After incubation at $35 \pm 1^{\circ} \mathrm{C}$ for $24 \mathrm{~h}$ zone sizes were measured. Isolates showing inhibition zone size $\leqslant 19 \mathrm{~mm}$ were considered as resistant as Methicillin resistant Staphylococcus aureus (MRSA). Standard stains used were ATCC 33591 (MRSA) and ATCC 29213 (MSSA) [11].

\section{Results}

One hundred and twenty food samples were randomly collected constituting 20 samples from each source from different food vendors and fast food joints during the study period July to Dec 2015 in Tumkur.

Food samples collected from different food vendors and fast food joints were used as specimen for isolation of causative agents. Table 1 shows the bacterial agents isolated from food samples.

Out of the 120 samples collected 96 samples showed the presence of pathogens. Salads were highly contaminated which yielded Staphylococcus aureus from food obtained from 19 food outlets, followed by cut fruits, fast food -1 and fast food -2 yielding Staphylococcus aureus and Escherichia coli. Table 2 shows the antibiogram of the isolates.

The antibiotic sensitivity revealed that, Staphylococcus aureus were resistant to ampicillin, gentamicin (23.95\%) and ciprofloxacin (18.75\%), 10 of $28(35.71 \%)$ isolates were resistant to cefoxitin and considered as MRSA. Of the 26 $(27.08 \%)$ Escherichia coli isolated $16(61.56 \%)$ were resistant to ampicillin and ciporofloxacin, 10 (36.46) were resistant to ceftazidime, ceftazidime/clavulanic acid and cefotaxime.

Salmonella sps isolated were resistant to ampicilin, gentamicin, (20.88\%), and ciprofloxacin, amikacin, co-trimoxazole $(13.54 \%)$

The resistance exhibited by Shigella sps were only (2.08\%) to most of the antibiotics used. Vibrio sps showed resistance to ampicillin, gentamicin, ciprofloxacin, amikacin and co-trimoxazole $(62.50 \%)$.

Table-1: shows the causative agents in the suspected food samples.

\begin{tabular}{|c|c|c|c|c|c|c|c|}
\hline \multirow[b]{2}{*}{ Food samples } & \multicolumn{7}{|c|}{ Organism isolated } \\
\hline & : & 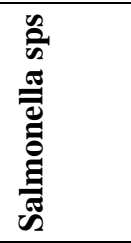 & 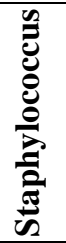 & 包 & 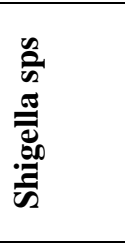 & 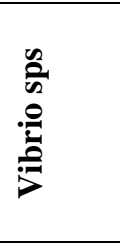 & 巳゙ \\
\hline Ice-cream & 4 & 4 & & 3 & - & - & 11 \\
\hline Salads & 3 & 5 & & 9 & 2 & - & 19 \\
\hline Milk products & 3 & 5 & & 3 & 1 & - & 12 \\
\hline Cut fruits & 4 & 4 & & 6 & 2 & 2 & 18 \\
\hline Fast food -1 & 6 & 3 & & 3 & 3 & 3 & 18 \\
\hline Fast food -2 & 6 & 3 & & 5 & 3 & 3 & 18 \\
\hline Total & 26 & 23 & & 28 & 11 & 08 & 96 \\
\hline
\end{tabular}


Table-2: Antibiogram of the isolates.

\begin{tabular}{|c|c|c|c|c|c|c|c|c|c|c|}
\hline \multirow[t]{2}{*}{ 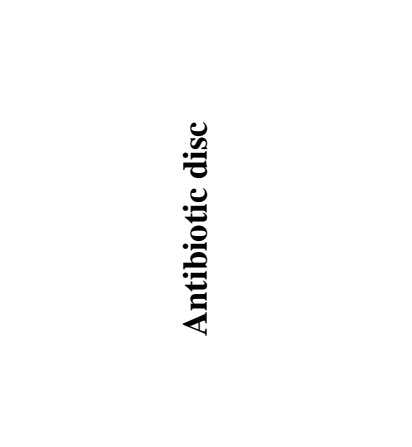 } & \multicolumn{2}{|c|}{ 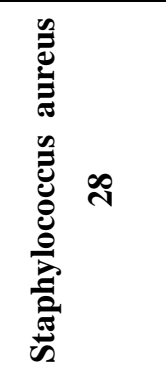 } & \multicolumn{2}{|c|}{ 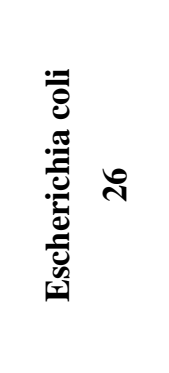 } & \multicolumn{2}{|c|}{ 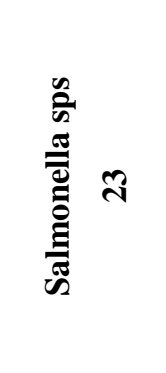 } & \multicolumn{2}{|c|}{ 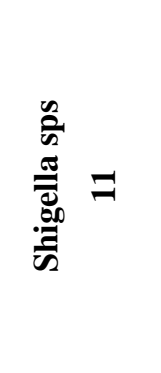 } & \multicolumn{2}{|c|}{$\frac{0}{n}$} \\
\hline & $\sim$ & $\simeq$ & $\sim$ & $\simeq$ & $\sim$ & $\simeq$ & $\sim$ & $\simeq$ & $\Omega$ & $\simeq$ \\
\hline Ampicillin & 05 & 23 & 10 & 16 & 03 & 20 & 09 & 02 & 03 & 05 \\
\hline Gentamicin & 05 & 23 & 06 & 20 & 03 & 20 & 09 & 02 & 03 & 05 \\
\hline Ciprofloxacin & 10 & 18 & 10 & 16 & 10 & 13 & 09 & 02 & 05 & 03 \\
\hline Amikacin & 18 & 10 & 23 & 03 & 10 & 13 & 09 & 02 & 03 & 05 \\
\hline Amoxycillin/ clavulanic acid & 18 & 10 & 16 & 03 & 20 & 03 & 09 & 02 & 05 & 03 \\
\hline Co-trimoxazole & 18 & 10 & 23 & 03 & 10 & 13 & 09 & 02 & 03 & 05 \\
\hline Cefotaxime & 10 & 10 & 16 & 10 & 20 & 03 & 11 & 00 & 08 & 00 \\
\hline Ceftazidime & -- & -- & 16 & 10 & 20 & 03 & 11 & 00 & 08 & 00 \\
\hline Ceftazidime/clavulanic acid & -- & -- & 16 & 10 & 20 & 03 & 11 & 00 & 08 & 00 \\
\hline Nalidixic acid & -- & -- & 10 & 16 & 20 & 03 & 11 & 00 & 08 & 00 \\
\hline
\end{tabular}

\section{Discussion}

High moisture content accelerates food spoilage and generally provides a good media for the growth and proliferation of microorganisms especially bacteria [12].

Food handling practices has been one of the leading cause of food-borne illness globally especially in the developing countries. Street food has been on the rise encouraged by the growing urban population and public demand for readily available cheep food. Consumers who depend on street food are more interested in its convenience than safety, quality and hygiene $[3,13]$.

Among the sources studied, it was found that the bacterial counts of salads were $19.79 \%$ followed by cut fruits, fast food-1 and 2, 18.75\%. Staphylococcus aureus (7.26\%), E.coli and (5.20\%) Salmonella sps respectively. The reason for high counts of Staphylococcus aureus could be due to poor personal hygiene of the food handlers and lack of heat processing steps during preparation. The serving utensils used at vending sites are often contaminated with Staphylococcus sps. Therefore not only from the food vendors hands but also dish, clothes and water used during dish washing and hand washing, indicates cross contamination between dish water, food preparation surfaces and the food itself consequently is a major health risk. Staphylococcus aureus is the most common agent of food poisoning followed by Salmonella sps. Similar observations were made in different studies [14,15]

In fast food 1 and fast food 2 the counts of E.coli were high $(6.25 \%)$. The presence of high numbers of coliforms indicates inadequate processing or post processing recontamination due to raw materials, dirty equipment or poor handling as well as microbial proliferation allowing multiplication of a wide range of pathogenic and toxigenic organisms. E.coli is an indicator of faecal contamination. These organisms are often spread from person to person. Both animals and people infected with the bacteria can be carriers.

Therefore proper hygiene, safe food handling and preparation practice share the key to preventing foodborne illness. If the food vendors are infected with E.coli or has any other gastrointestinal illness they should be advised not to prepare food for others or safety food handling procedures should be followed like wearing disposable hand gloves etc $[16,17]$. 
Ice creams were contaminated with Salmonella sps and E.coli. Cold temperature, milk, water used in preparation may be the possible cause of contamination $[8,18]$.

In the present study most of the food samples were contaminated with bacteria such as Staphylococcus aureus, E.coli, Salmonella sps, Shigella sps and Vibrio sps. All these pathogens are responsible for food-borne illness. Many studies reveal the presence of bacterial contamination of food involving these microorganisms [8].

Most food pathogens of soil or intestinal origin are transmitted through poor food preparation, improper personal hygiene or public sanitation practices. It is important therefore to ensure the safety of food. Street food vendors and fast-food joints must maintain a clean environment to minimize contact with the food sample after production. Utensils should be properly cleaned at all stages of production [19].

Antibiotic sensitivity of the isolates could increase the incidence of diarrhoeal illness, typhoid and several community acquired infections especially among those with compromised immune system. Therefore surveillance and monitoring should be of great concern in the community [3].

\section{Conclusion}

Food-borne illness has made an impact world wide. In the recent past an enormous increase in the nature of food-borne illness and number of food-borne pathogens has been documented. A major problem in maintaining food safety is the need to rapidly detect microorganisms in order to curb outbreaks that can affect large population. Increased consumption of food from commercial food service establishments has lead to potential out-breaks caused by infected food handlers. Education of the public and eating establishments is crucial to the control of food borne illness.

It is an accepted fact that street foods are heavily contaminated with microorganisms. The present study reveals $80 \%$ of the street foods are positive for food borne pathogens. Our findings indicate the need for implementation of food sanitation code and licensing of street food vendors.

Funding: Nil, Conflict of interest: None initiated, Permission from IRB: Yes

\section{References}

1. Frazier WC, Westhoff DC. Food Microbiology $4^{\text {th }}$ Edn. New Delhi Tata McGraw-Hill Publishing Company Limited, 2000.

2. Zeru K, Kumie A. Sanitary Conditions of food establishments in Melella Towm, Tigary, North Ethiopia. Ethiop. J. Health Dev 2002; 21(1):3-11.

3. Zige DV, Ohimain EI, Sridhar KC. Enteric Bacteria from ready to eat food vended in Amassoma community in Niger Delta and its health implication. IOSR Journal of Environmental Science, Toxicology And Food Technology (IOSR-JESTFT).2013;6(4):62-5.

4. Nurudeen AA, Lawal AO, Ajayi SA. A survey of hygiene and sanitary practices of street food vendors in the Central State of Northern Nigeria. Journal of Public Health and Epidemiology. 2014 May 19;6(5):174-81.

5. Codex Alimentarius Commission. Revised Regional Guidelines for the Design of Control Measures for Street-Vended Foods in Africa. CAC/GL-22-Rev.1; 1999.

6. Gawande HA, Mishra AA, Shukla RN, Jain J. Socioeconomic profile of street food vendors and quality evaluation of Samosa and Panipuri in Allahabad City (UP), India. International Journal of Agriculture and Food Science Technology 2013; 4(3):275-80.

7. Janie P, Marie T. Street food in Kolkata-A hygienic perspective Project in practice 400040.

8. Tambekar DH, Kulkarni BV, Shirsat SD, Bhadange DG. Bacteriological Quality of Street vended food Panipuri: A case study of Amarvathi city (MS) India. Bioscience Discovery 2011; 2(3):350-54.

9. Collee JG, DuguidJP, Fraser AG, Marmion BP, Simmons A. 1996. Mackie and McCartney Practical Medical Microbiology. 14 ${ }^{\text {th }}$ Edn. New Delhi. Harcourt Brace and Company limited.2006

10. Collins CH, Patricia M L, Grange JM. Microbiology Methods $7^{\text {th }}$ Edn. London. Butterworth \& Co (Publishers) Ltd. 1995.

11.Clinical Laboratory Standards Institute. Performance Standards for Antimicrobial Testing: Twentyfifth 


\section{Research Article}

Informational Supplement CLSI document M100-S17; 2015.

12. Madueke SN, Awe S, Jonah AI. Microbiological analysis of street foods along Lokoja-Abuja express way, Lokoja. American Journal of Research Communication. 2014; 2(1):196-211.

13. Tuladhar R, Singh A. Bacterial Analysis and Survey of the Street Food of Kathmandu in Relation to Child Health. Journal of Natural History Museum. 2015 Dec $17 ; 26(1): 1-9$.

14. Mensah P, Yeboah-Manu D, Owusu-Darko K, Ablordey A. Street foods in Accra, Ghana: how safe are they? Bull World Health Organ. 2002;80(7):546-54. Epub 2002 Jul 30.

15. Derbew G, Sahle S, Endris M. Bacteriological assessment of some street vended foods in Gondar, Ethiopia. Internet J Food Safety. 2013; 15:33-8.
16. Poojara RH, Krishna G. Microbiological profile of street vended foods in Cochin, Kerala India. Biosci. Discov. 2012; 3 (2): 179-85. Mathur P, Reddy V. Bacterial contamination of infant foods. IJMR1983; 77: 342-6.

17. Mathur R, Reddy V. Bacterial contamination of infant foods. Indian J Med Res. 1983 Mar;77:342-6.

18. Głośnicka R, Kunikowska D. The epidemiological situation of Salmonella enteritidis in Poland. International journal of food microbiology. 1994 Jan 1; $21(1-2): 21-30$.

19. Chauhan N, Uniyal V, Rawat DS. Microbial profile of street foods in different locations at Dehradun city, India. J. Biol. Agri. Health. 2015; 4(1);340-7.

\section{How to cite this article?}

Sudeep Kumar M, Krishnamurthy Veena, E R Nagaraj. Microbial profile of street food from different locations at Tumkur, India. Trop J Path Micro 2017;3(2):84-89.doi: 10.17511/jopm.2017.i2.01. 